Vol. 24, No. 1, Januari 2021, hlm. 159-166

p-ISSN: 1410-9344; e-ISSN: 2549-5631

WARTA LPM

homepage: http://journals.ums.ac.id/index.php/warta

\title{
Memahami Konsep Ilmiah Strategi Belajar Bahasa Ke-dua Sebagai Pengembangan Kompetensi Pedagogis Guru
}

\author{
Endang Fauziati, Karmila, Shakesha Febrisha Shektasari \\ Universitas Muhammadiyah Surakarta JL. A. Yani Tromol Pos 1 Surakarta \\ Email: endang.fauziati@ums.ac.id, s400190004@student.ums.ac.id, A320160276@student.ums.ac.id
}

\begin{tabular}{l}
\hline \multicolumn{1}{c}{ Article Info } \\
\hline Submitted: 9 July 2020 \\
Revised: 21 November 2020 \\
Accepted: 27 November 2020 \\
Published: 30 December 2020 \\
Keywords: Second language \\
learning strategies, pedagogical \\
competencies, understanding \\
learners
\end{tabular}

Kata kunci: Strategi belajar bahasa ke-dua, kompetensi pedagogik, memahami peserta didik

\begin{abstract}
Teachers as key figures in the educational process are required to have several competencies including pedagogical competencies. One of the pedagogical competencies is to understand learners' characteristics that should be considered in program design and teaching learning process. One of the issues related to learners is the second language learning strategy, which is the focus of this community's dedication. From the preliminary study it was fond that most teachers had the least understanding of the scientific concepts of the second language learning strategy. To that end, community service was conducted. With this scientific conceptual understanding teachers are expected to apply it in both teaching learning process and research. Community service was conducted in the form of workshop through Zoom and Schoology applications. Overall the workshop ran well. Participants were actively involved in each planned session. One of the indicators of success is that participants were able to explain the second language learning strategy conceptually based on the relevant theory. Participants were also able to make relevant research topics. From the results of this activity, it is suggested that this program be continued in the future.
\end{abstract}

Abstrak
Guru sebagai tokoh utama dalam proses pendidikan dituntut untuk
memiliki beberapa kompetensi termasuk kompetensi pedagogis.
Salah satu kompetensi pedagogis adalah memahami peserta didik
yang dapat dijadikan pertimbangan dalam penyusunan program dan
proses belajar mengajar. Salah satu hal terkait dengan peserta didik
adalah strategi pembelajaran bahasa ke-dua, yang merupakan fokus
pengabdian masyarakat ini. Dari studi awal diperoleh gambaran
bahwa rata-rata guru belum menguasai konsep ilmiah tentang strategi
belajar bahasa ke-dua secara memadai. Umumnya jawaban para guru
masih bersifat volk knowledge. Untuk itu, pengabdian masyarakat ini
dilaksanakan. Dengan pemahaman konseptual ilmiah ini para guru
diharapkan dapat mengaplikasikannya dalam pembelajaran maupun


penelitian. Pengabdian masyarakat ini dilaksanakan dengan model workshop melalui aplikasi Zoom dan Schoology. Secara keseluruhan loka karya berjalan lancar. Peserta terlibat secara aktif dalam setiap sesi yang telah direncanakan. Salah satu indikator keberhasilannya adalah peserta mampu menjelaskan strategi belajar bahasa ke-dua (language learning strategy) secara konseptual berdasarakan teori yang relevan. Peserta juga mampu membuat topic penelitian yang relevan. Dari hasil kegiatan ini, disarankan agar program ini dapat dilanjutkan di masa mendatang.

\section{PENDAHULUAN}

Guru merupakan tokoh utama dalam proses pendidikan. Untuk itu, guru dituntut untuk memenuhi persyaratan dan kompetensi profesional yang diperoleh melalui pendidikan di LPTK. Guru yang memiliki kemampuan profesional yang disandangkan dalam jabatan guru sebagai sebuah profesi. Undang-Undang Guru (pasal 1 ayat 1) menyatakan bahwa guru merupakan pendidik profesional dengan tugas utama mendidik, mengajar, membimbing, mengarahkan, melatih,menilai, danmengevaluasi peserta didik pada pendidikan anak usia dini, jalur pendidikan formal, pendidikan dasar, dan pendidikan menengah. Dengan demikian, profesi guru merupakan jabatan profesional yang memiliki tugas pokok dalam proses belajar mengajar. Tugas pokok profesi guru tersebut meliputi seluruh komponen proses pendidikan dan peserta didik.

Sebagai jabatan profesional guru dituntut untukmemiliki kompetensi-kompetensitertentu. Undang-Undang Republik Indonesia Nomor 14 Tahun 2005 tentang Guru dan Dosen menyatakan bahwa kompetensi adalah seperangkat pengetahuan, keterampilan, dan perilaku yang harus dimiliki, dihayati, dan dikuasai oleh guru atau dosen dalam melaksanakan tugas keprofesionalan. Finch \& Crunkilton (1992) menyatakan bahwa kompetensi merupakan tugas, keterampilan, sikap, nilai-nilai, dan penghargaan yang dianggap penting untuk keberhasilan pekerjaan. Sedangkan Robbin (2008) menyatakan bahwa kompetensi merupakan suatu kemampuan (ability) atau kapasitas seseorang untuk melakukan berbagai tugas dalam suatu pekerjaan. Jadi, unsur kompetensi meliputi tugas, keterampilan, sikap, nilai, apresiasi yang diberikan. Dan kompetensi guru merupakan indikator yang dapat dijadikan alat ukur karakteristik guru yang kompeten secara profesional.

Kompetensi guru merupakan perpaduan antara kompetensi personal, keilmuan, teknologi, sosial, dan spiritual yang secara utuh membentuk kompetensi standar profesi guru. Undang-Undang Nomor 14 Tahun 2005 tentang Guru dan Dosen, pada pasal 10 ayat (1) menyatakan bahwa "Kompetensi guru sebagaimana dimaksud dalam Pasal 8 meliputi kompetensi pedagogis, kompetensi kepribadian, kompetensi sosial, dan kompetensi profesional yang diperoleh melalui pendidikan profesi". Berdasarkan undang-undang tersebut, salah satu kompetensi guru adalah kompetensi pedagogis. Beberapa sub kompetensi pedagogis meliputi: (1) Memahami peserta didik secara mendalam yang meliputi memahami peserta didik dengan memamfaatkan prinsip-prinsip perkembangan kognitif, prinsip-prinsip kepribadian, dan mengidentifikasi bekal ajar awal peserta didik; (2) Merancang pembelajaran, termasuk memahami landasan pendidikan untuk kepentingan pembelajaran yang meliputi memahmi landasan pendidikan, menerapkan teori belajar dan pembelajaran, menentukan strategi pembelajaran berdasarkan karakteristik peserta didik, kompetensi yang ingin dicapai, dan materi ajar, serta menyusun rancangan pembelajaran berdasarkan strategi yang dipilih; (3) Melaksanakan pembelajaran yang meliputi menata latar (setting) pembelajaran dan melaksanakan pembelajaran yang kondusif; (4) Merancang dan melaksanakan evaluasi pembelajaran yang meliputi merancang dan melaksanakan evaluasi (assessment) proses dan hasil belajar secara berkesinambungan denga berbagai metode,menganalisis hasil evaluasi 
proses dan hasil belajar untuk menentukan tingkat ketuntasan belajar (mastery level), dan memamfaatkan hasil penilaian pembelajaran untuk perbaikan kualitas program pembelajaran secara umum; dan mengembangkan peserta didik untuk mengaktualisasikan berbagai potensinya meliputi memfasilitasi peserta didik untuk pengembangan berbagai potensi akademik, dan memfasilitasi peserta didik untuk mengembangkan berbagai potensi nonakademik.

Memahami peserta didik merupakan salah satu kompetensi pedagogis yang harus dimiliki oleh guru. Hal ini bertujuan agar guru dapat mengetahui karakteristik peserta didik yang dapat dijadikan bahan pertimbangan dalam penyusunan program yang tepat, sehingga proses belajar mengajar dapat memenuhi kebutuhan, minat, bakat, kemampuan, keinginan, dan tuntutan mereka serta sesuai dengan perkembangan mereka. Beberapa pertimbangan antara lain pertimbangan perkembangan fisik, psikologis, kognitif, moral, dan sosial. Salah satu hal terkait dengan peserta didik yang harus dipahami guru adalah terkait dengan strategi belajar (language learning strategy).

Relevan dengan topik pengabdian masyarakat ini, yaitu strategi belajar bahasa ke-dua, secara ringkas dapat dinyatakan bahwa strategi pembelajaran merupakan pendekatan individu pembelajar untuk menyelesaikan tugas atau kegiatan belajarnya. Oxford (2002) menyatakan bahwa strategi belajar bahasa asing atau bahasa kedua merupakan specific behaviors or thought processes that students use to enhance their own second language learning, maksudnya cara individu pembelajar dalam mengatur dan menggunakan seperangkat keterampilan tertentu untuk mempelajari konten atau menyelesaikan tugas-tugas pembelajaran secara lebih efektif dan efisien baik di lingkungan sekolah maupun di lingkungan non-akademik. Dengan demikian, strategi belajar bahasa ke-dua (second language learning strategy) merupakan proses pikiran dan tindakan secara sadar yang dilakukan oleh pembelajar guna mencapai atau menyelesaikam tujuan pembelajarannya. Pembelajar yang strategis dan efektif umumnya memiliki pengetahuan meta kognitif tentang pemikiran dan pendekatan pembelajaran mereka sendiri. Mereka memiliki pemahaman yang baik tentang tugas yang harus dilakukan serta kemampuan untuk mengatur strategi yang paling baik untuk memenuhi tuntutan tugas dan kekuatan belajar mereka sendiri (Chamot, 2008). Dengan demikian, strategi belajar bahasa kedua memungkinkan pembelajar untuk menjadi pembelajar mandiri sepanjang masa (Oxford, 2002).

Dari interview dengan enam guru-guru Bahasa Inggris di SMP Muhammadiyah 4, 5, dan 6 sebagai studi awal diperoleh gambaran bahwa rata-rata guru belum menguasai konsep ilmiah tentang strategi belajar bahasa ke-dua secara memadai. Pemahaman mereka masih bersifat volk-knowledge dan kurang ilmiah. Misalnya, umumnya guru menyatakan bahwa strategi belajar adalah strategi yang digunakan siswa saat belajar bahasa Inggris. Untuk itu, pengetahuan para guru tentang konsep ilmiah strategi belajar bahasa ke-dua perlu ditingkatkan. Gambaran permasalahan ini menunjukkan bahwa para guru perlu memperoleh wawasan konseptual ilmiah tentang strategi belajar bahasa kedua yang merupakan salah satu unsur dalam kompetensi pedagogik, khususnya pemahaman peserta didik. Dengan pemahaman konseptual ilmiah ini para guru selanjutnya diharapkan dapat mengaplikasikannya dalam pembelajaran maupun penelitian. Guru diharapkan sekaligus sebagai peneliti dalam proses belajar mengajarnya. Guru, selain sebagai praktisi yang melaksanakan serangkaian proses pembelajaran juga diharapkan dapat melakukan evaluasi yang antara lain dapat dilakukan melalui penelitian.

Konsep guru peneliti mengharapkan guru untuk menginventarisir berbagai permasalahan yang dihadapi selama proses belajar mengajar. Dan sebagai tindak lanjut, guru diharapkan untuk merencanakan penyelesaian permasalahan dalam bentuk tulisan yang ilmiah. Dengan demikian, guru akan terbiasa dengan penelitian dan penulisan secara ilmiah yang bermanfaat bagi proses belajar mengajar maupun perkembangan karirnya sebagai guru profesional. Selain itu, akan terhubung secara nyata antara konsep dan praktik.

Lokakarya ini dilaksanakan secara daring pada Tanggal 27 Juni 2020 melalui aplikasi Zoom. Adapun materi pembekalan yang akan 
disampaikan berkenaan dengan Factors which contribute to the success in foreign language learning and language learning strategy. Kegiatan ini juga digunakan sebagai ajang promosi tentang Universitas Muhammadiyah Surakarta pada umumnya, Fakultas Keguruan dan Ilmu Pendidikan, dan Program studi Pendidikan Bahasa Inggris pada khususnya.

Literatur yang relevan menjelaskan tentang berbagai faktor yang berkontribusi pada penguasaan bahasa kedua, antara lain motivasi, sikap, usia, kecerdasan, bakat, kepribadian, gaya belajar, dan strategi belajar (Ellis, 2008). Beberapa faktor dikatakan sebagai dominan dan beberapa faktor lainnya sama, akan tetapi masingmasing memberikan kontribusi yang berbeda untuk keberhasilan atau kegagalan penguasaan bahasa kedua. Tidak diragukan lagi bahwa setiap anak normal dan dibesarkan secara normal semuanya berhasil memperoleh atau menguasai bahasa pertama mereka (Heidar, 2012). Namun, pengalaman empiris menunjukkan bahwa tidak semua pembelajar bahasa ke-dua dapat berhasil atau sukses dalam memperoleh atau menguasai bahasa ke-dua (Heidar, 2012). Hasil capaian mereka beragam karena adanya faktorfaktor yang mempengaruhi proses penguasaan bahasa ke-dua tersebut. Makalah pengabdian masyarakat ini hanya berfokus pada salah satu faktor, yaitu lokakarya tentang strategi belajar bahasa ke-dua.

Strategi belajar bersifat netral nilai, artinya tidak dapat dikategorikan menjadi strategi baik atau buruk. Strategi belajar sangat bermanfaat bagi pembelajar apabila cocok atau sesuai dengan tugas pembelajaran dan dengan gaya belajarnya. Dalam kondisi ini, strategi belajar dapat membuat proses belajar lebih mudah, lebih cepat, lebih menyenangkan, lebih mandiri, lebih efektif, dan lebih dapat ditransfer ke situasi baru (Oxford, 2002). Oleh karena itu, guru yang profesional dapat mengajarkan peserta didik bagaimana strategi belajar yang dapat diaplikasikan oleh pembelajar. Guru juga dapat membuat pembelajar waspada terhadap strategi belajar yang digunakan dan dapat menggunakannya untuk meningkatkan pembelajaran mereka sendiri.

O’Malley \& Chamot (1990) membagi strategi belajar menjadi tiga subkategori utama, yaitu: strategi meta-kognitif, strategi kognitif, dan strategi sosial-afektif. Pertama, strategi meta-kognitif mengacu pada istilah yang digunakan dalam teori pemrosesan informasi untuk menunjukkan fungsi eksekutif, yaitu, strategi yang melibatkan perencanaan untuk belajar, berpikir tentang proses pembelajaran seperti yang sedang terjadi, memantau produksi seseorang atau pemahaman, dan mengevaluasi pembelajaran setelah suatu kegiatan selesai. Di antara strategi meta-kognitif utama meliputi organisator tingkat lanjut, perhatian terarah, perhatian selektif, manajemen diri, perencanaan fungsional, pemantauan diri, produksi tertunda, dan evaluasi diri. Kedua, strategi kognitif lebih terbatas pada strategi belajar tertentu dan melibatkan lebih banyak manipulasi kognitif secara langsung dari bahan pembelajaran itu sendiri. Kelompok kedua ini meliputi strategi kognitif yang paling penting antara lain pengulangan, sumber daya, terjemahan, pengelompokan, pembuatan catatan, deduksi, rekombinasi, citra, representasi pendengaran, kata kunci, kontekstualisasi, elaborasi, transfer, dan penarikan kesimpulan. Dan yang ketiga, strategi sosial-afektif merupakan strategi yang dilakukan dengan kegiatan mediasi sosial dan berinteraksi dengan orang lain. Bekerjasama, bertanya untuk klarifikasi, memaknai suasana hati merupakan beberapa contoh strategi sosialafektif utama (Brown, 2002).

Berdasarkan latar belakang tersebut di atas, kegiatan pengabdian tahap awal ini diarahkan pada penyampaian materi workshop guru bahasa Inggris mitra dengan tujuan untuk memberikan pengetahuan berupa konsep ilmiah tentang strategi belajar bahasa (language learning strategy) kepada para guru bahasa Inggris agar mereka memiliki landasan konsep ilmiah yang selanjutnya dapat diaplikasikan dalam penelitian. Workshop tentang learning strategy ini merupakan proses pengayakan keilmuan yang diperlukan para guru dalam proses belajar mengajar dan mengevaluasi programnya. Di dalam workshop atau lokakarya ini dibahas semua aspek tentang faktor-faktor yang berkontribusi dalam penguasaan bahasa ke-dua, dengan penekanan khusus pada konsep strategi belajar bahasa ke-dua sebagai modal akademik dalam penelitian dan penulisan karya ilmiah dan pengembangan karir guru. 
Hasil pelaksanaan loka karya ini diharapkan dapat berguna dan memberikan manfaat secara teoretis maupun praktis. Secara umum hasil pelaksanaan lokakarya ini diharapkan dapat memberikan sumbangan pemikiran (insights) dalam memperluas wawasan konsep strategi belajar bahasa ke-dua terutama dalam bahasa Inggris sebagai bahasa asing. Secara praktis, hasil pengabdian masyarakat ini dapat dijadikan bahan masukan (feedbacks) bagi guru agar lebih memahami peserta didiknya, utamanya terkait learning strategy. Program sertifikasi guru dalam jabatan dilakukan melalui penilaian portofolio (Permendiknas No.18 Tahun 2007) yang meliputi beberapa komponen yang salah satunya adalah karya pengembangan profesi (komponen butir ke 7). Dengan demikian, para guru dituntut untuk memiliki kemampuan melaksanakan penelitian dan penulisan karya ilmiah. Namun, dalam kenyataannya para guru masih banyak mengalami kesulitan untuk menulis karya ilmiah. Salah satu penyebabnya adalah adanya keterbatasan pemahaman konsep ilmiah yang dapat dikembangkan dalam karya ilmiah. Untuk itu, kegiatan lokakarya ini dimaksudkan untuk memberi pembekalan konsep ilmiah yang selanjutnya dapat dijadikan modal untuk penulisan karya ilmiah bagi para guru. Diharapkan bahwa setelah loka karya ini para guru memperoleh insights untuk penulisan karya tulis ilmiah.

Adapun solusi yang ditawarkan untuk menyelesaikan permasalahan mitra adalah sebagi berikut: (1) lokakarya tentang faktor yang berkontribusi terhadap penguasaan bahasa asing (Inggris); (2) penulisan topik karya ilmiah yang akan dingkat dalam penulisan karya ilmiah; dan (3) perumusan masalah yang akan diangkat dalam penulisan karya ilmiah.

\section{METODE}

Metode pelaksanaan kegiatan pengabdian masyarakat ini dilakukan melalui beberapa tahap, sebagai berikut. (1) Menghubungi mitra dan mendiskusikan permasalahan yang dihadapi terkait dengan pembelajaran bahasa Inggris, khususnya terkait dengan kompetensi pedagogis, (2) Membahas program kegiatan yang bisa dilakukan bersama untuk mengatasi persoalan yang dihadapi, (3) Menghubungi prodi bahasa Inggris untuk memastikan terlaksananya kegiatan lokakarya ini dan memastikan waktu pelaksanaan, (4) Melaksanakan pendaftaran peserta dan membahas rencana pelaksanaan kegiatan yang disepakati, dan (5) Lokakarya dilaksanakan melalui aplikasi Zoom pada Tanggal 27 Juli 2020, mulai pukul 12.30 sampai dengan pukul 16.00. Kegiatan kemudian dilanjutkan dengan aplikasi Schoology untuk menyelesaikan tugas-tugas workshop dan diskusi yang lebih mendalam.

\section{HASIL DAN PEMBAHASAN}

Program pengabdian masyarakat ini dilaksanakan dengan mitra Program Studi Pendidikan Bahasa Inggris UMS, yaitu guruguru bahasa Inggris di sekolah mitra, yaitu Sekolah Menengah Pertama (SMP) di Surakarta. Seluruh rencana kegiatan dapat terlaksana dengan baik. Jumlah peserta ada 31 guru bahasa Inggris yang terdiri dari 4 laki-laki dan 27 perempuan. Para peserta berasal dari sekolah mitra, Sekolah Menengah Pertama di Surakarta. Sekolah mitra dalam pengabdian masyarakat saat ini adalah antar lain 19 Sekolah Menengah Pertama Muhammadiyah Surakarta, 9 SMP Negri Surakarta, dan 3 SMP swasta nonMuhammadiyah di Surakarta.

Secara keseluruhan lokakarya berjalan dengan tertib dan lancar. Para peserta cukup antusias dalam mengikuti program ini. Hal ini terindikasi dari berbagai pertanyaan, komentar, dan usulan terkait dengan topik lokakarya. Beberapa hal yang diungkap antara lain: (1) mengapa kemampuan bahasa Inggris siswa tidak sama pada hal mereka memperoleh kesempatan yang sama, diajar oleh guru yang sama, dan dengan proses belajar mengajar yang sama pula; dan (2) ada kecenderungan siswa perempuan lebih aktif dibanding siswa laki-laki saat mengikuti proses pembelajaran bahasa Inggris. Jawaban dari permasalahan secara luas disampaikan. Namun, selanjutnya oleh narasumber diarahkan ke topik lokakarya ini, yaitu memahami peserta didik, utamanya terkait dengan language learning strategy. Banyak faktor yang berkontribusi pada sukses tidaknya penguasaan bahasa ke-dua, dan salah satunya adalah strategi belajar. 
Dengan lokakarya ini diharapkan para guru memahami konsep strategi belajar bahasa sehingga dapat membuat solusi atas hal-hal yang dihadapi siswa. Guru memiliki pemahaman terhadap siswanya. Selain itu perlu ditekankan bahwa tidak ada siswa bodoh atau siswa pintar dalam mempelajari bahasa Inggris. Yang ada adalah siswa yang baik dan kurang baik dalam mempelajari bahasa Inggris. Rubin (1975) pakar pemerolehan bahasa ke-dua, menyebutnya sebagai good language learners.

\section{Relevan dengan yang disampaikan oleh Hedge (2000) pembelajar bahasa} yang memiliki strategi belajar yang baik dan memiliki kemandirian dalam belajar (autonomous learner) sangat memungkinkan bahwa pembelajar tersebut akan lebih berhasil dari pada pembelajar yang hanya bergantung pada guru untuk segala sesuatu dan yang mengikuti apa saja secara acak tanpa mencoba memproses informasi dan menjadikannya milik mereka sendiri. Hal yang demikian bisa dikatakan bahwa pembelajar tersebut menjadi self directed, mampu mengarahkan diri sendiri. Artinya, pembelajar tersebut memiliki motivasi untuk belajar mandiri dengan berbagai strategi belajar yang sesuai dan bersedia melakukan apapun untuk menyelesaikan tugas-tugas pembelajarannya.

Hedge (2000) menambahkan bahwa pembelajar bahasa ke-dua yang baik (good language learners) merupakan pembelajar yang mampu mengarahkan dirinya sendiri dalam belajar (self directed learners). Mereka ini memiliki ciri khas, antara lain: (1) mampu mengarahkan diri sendiri untuk mengetahui kebutuhan mereka dan bekerja secara produktif dengan guru untuk mencapai tujuannya; (2) mengetahui cara menggunakan sumber daya secara mandiri; (3) mampu belajar baik di dalam maupun di luar kelas; (4) mampu menyesuaikan strategi belajar mereka sesuai kebutuhan; (5) mampu mengatur dan membagi waktu dalam belajar dengan benar; (6) mandiri dalam belajar dengan berpikir aktif; dan (7) tidak berpikir bahwa guru adalah dewa yang bisa memberi mereka segalanya.

Pelaksanaan kegiatan lokakarya dapat dideskripsikan sebagai berikut. Kegiatan lokakarya ini dimulai dengan pembukaan oleh unsur pimpinan prodi pendidikan bahasa Inggris, dalam kesempatan ini diwakili oleh sekretaris prodi 1 dan 2, yaitu Ibu Aryati Prasetyarini, S.Pd., M.Hum dan Ibu Susiati, S.Pd., M.Ed. Disampaiknan oleh pimpinan prodi bahwa kegiatan lokakarya ini merupakan salah satu perwujudan kegiatan pengabdian kepada masyarakat, yang merupakan salah satu bagian dari Tri Dharma Perguruan Tinggi. Kegiatan ini diselenggarakan oleh prodi bahasa Inggris secara reguler dan dilaksanakan dengan menggandeng sekolah mitra prodi. Kegiatan ini bertujuan untuk membantu masyarakat tertentu dalam berbagai aktivitas yang relevan tanpa imbalan dalam bentuk apapun, alias gratis. Secara umum program ini dirancang oleh prodi bahasa Inggris untuk memberikan kontribusi nyata bagi sekolah mitra, khususnya dalam mengembangkan profesi guru. Selain itu, tentu saja ada kegiatan pengabdian masyarakat dalam bentuk bakti sosial.

Acara dilanjutkan dengan perkenalan peserta lokakarya meliputi nama dan asal institusi. Selanjutnya, waktu dan floor diserahkan kepada narasumber. Disampaikan kepada para peserta bahwa inti kegiatan ini bertujuan untuk pengembangan profesi guru. Secara rinci dijelaskan tentang latar belakang lokakarya, tujuan yang ingin dicapai, target atau luaran lokakarya, serta alur lokakarya. Setelah penjelasan tentang alur pelatihan, peserta diberikan kesempatan untuk memperkenalkan diri, meliputi nama dan asal institusi.

Kegiatan lokakarya kemudian dilanjutkan dengan sesi presentasi oleh narasumber (Prof. Endang Fauziati) tentang faktor yang berkontribusi pada penguasaan bahasa kedua, terutama language learning strategy. Dalam paparannya dijelaskan secara lengkap tentang language learning strategy, meliputi (1) pengertian menurut beberapa pakar, (2) hubungan antara language learning strategy dan penguasaan bahasa ke-dua, (3) berbagai taxonomi tentang language learning strategy antara lain dari Rubin (1987), O'Malley \& Chamot (1990), Stern (1992), dan Oxford (2002), dan (4) metode penelitian tentang language learning strategy. Selesai pemaparan oleh nara sumber utama, kegiatan loka karya dilanjutkan dengan sesi tanya jawab. Semua 
kegiatan ini dilaksanakan melalui aplikasi Zoom.

Kegiatan lokakarya kemudian dilanjutkan dengan sesi workshop melalui aplikasi Schoology. Desain kegiatan workshop adalah dengan model classroom. Peserta dibuatkan sebuah ruang kelas dengan nama "2020 Workshop Mitra DEE" dengan access code "XMRF-D9ZZ-TX47T". Dalam ruang Schoology ini peserta dapat mengakses materi lengkap tentang topik yang dibahas. Selanjutnya peserta diberi tugas untuk membuat tema penulisan karya ilmiah. Hasil tulisan diminta untuk submit lewat Schoology tersebut.

Beberapa tema atau topik penulisan karya ilmiah hasil lokakarya adalah sebagai berikut: Cognitive Strategies In Developing Reading Skills: A case Study at A Junior High School Surakarta. Meta Cognitive Strategy in Promoting English used by Students of Junior High School in Surakarta. Socio-affective strategy used by EFL students in Developing their Speaking Skills. Diaries of language Learning Strategy of A Good Language Learner.

Dalam sesi refleksi, peserta lokakarya menyatakan bahwa program pengabdian masyarakat ini telah memberikan manfaat bagi mitra dan peserta. Diharapkan bahwa kegiatan ini dapat ditindak lanjuti dengan program pengabdian masyarakat berikutnya. Sehingga, materi yang diperoleh pada kegiatan sekarang ini akan berkesinambungan dengan materi yang relevan berikutnya. Melalui program yang reguler dan berkesinambungan ini, peserta dapat memperoleh manfaat yang signifikan.

\section{SIMPULAN}

Pengabdian masyarakat ini bertujuan untuk mengembangkan kompetensi pedagogic peserta, khususnya terkait dengan strategi belajara bahasa ke-dua. Pengabdian masyarakat dilaksanakan dengan model lokakarya melalui aplikasi Zoom dan Schoology. Sekolah mitra yang terlibat antar lain 19 Sekolah Menengah Pertama Muhammadiyah Surakarta, 9 SMP Negri Surakarta, dan 3 SMP swasta nonMuhammadiyah di Surakarta. Lokakarya berjalan dengan baik; peserta terlibat secara aktif dalam setiap sesi yang telah direncanakan. Hasil lokakarya menunjukkan adanya perubahahan dalam pemahaman tentang topik bahahasan. Sebelum lokakarya umumnya pemahaman guru pada tataran volk knowledge dan setelah lokakarya guru memiliki kemampuan untuk menjelaskan secara teoritis konseptual. Dengan pemahaman konseptual ilmiah ini para guru diharapkan dapat mengaplikasikannya dalam pembelajaran maupun penelitian. Dari hasil kegiatan ini, dapat disarankan agar program pengabdian masyarakat di masa mendatang dapat memanfaatkan hasil pengabdian sekarang sebagai pijakan guna menyusun program selanjutnya yang relevan.

\section{UCAPAN TERIMA KASIH}

Program pengabdian masyarakat ini dapat terlaksana dengan baik atas dukungan dari Lembaga Penelitian dan Pengabdian Masyarakat Universitas Muhammadiyah Surakarta, Program Studi Pendidikan bahasa Inggris Universitas Muhammadiyah Surakarta, dan Sekolah Mitra.

\section{DAFTAR PUSTAKA}

Chamot, A. (2005). Language Learning Strategy Instruction: Current Issues and Research. Annual Review of Applied Linguistics, 25, 112-130.

Ellis, R. (2008). The Study of Second Language Acquisition (2nd ed.). New York: $\quad 0 \quad x \quad f \quad$ o $\quad r \quad d$ University Press.

Finch, \& Crunkilton. (1992). Curriculum Development in Vocational and Technical Education. Planning, content and implementation (4th ed.) Virginia: Polytechnic Institute and State University

Heidar, D. M. (2012). First Language Acquisition: Psychological Considerations and Epistemology. Theory and Practice in Language Studies, 2(2), 411-416.

Hedge, T. (2000). Teaching and Learning in the Language Classroom, Oxford, Oxford University Press. 
Fauziati, dkk - Memahami Konsep Ilmiah Strategi Belajar ...

Heidar, D. M. (2012). First Language Acquisition: Psychological Considerations and Epistemology. Theory and Practice in Language Studies, 2(2), 411-416. doi:10.4304/tpls.2.2.411-416. O'Malley, J \& Chamot, A (1990). Learning Strategies in Second Language Acquisition. Cambridge: Cambridge University Press.

Oxford, R. (2002). Language Learning Strategies. In r. Carter, \& d. Nunan (eds.), the Cambridge Guide to Teaching English to Speakers of Otherlanguages (pp. 166-172). Cambridge: Cambridge University Press.

Robbins, P. S. (2006). Perilaku Organisasi. Edisi Bahasa Indonesia. Jakarta: Gramedia.

Rubin, J. (1975). What the “Good Language Learner" Can Each Us? TESOL Quarterly, 9, 41-51. https:// doi.org/10.2307/3586011

Stern, H. H. (1975). What Can We Learn from the Good Language Learner? Canadian Modern Language Review, 31, 304-318.

Undang-Undang Nomor 14 Tahun 2005 tentang Guru dan Dosen 